\title{
Analysis Policy Implementation of New Student Admissions Zone System (Case studi In SMA N 1 Sunggal Deli Regency Serdang, 2018/2019)
}

\author{
Asaaro Laia \\ STKIP Nias Selatan Sumatera Utara \\ North Sumatra, Indonesia
}

\author{
Ekadaryanto \\ Universitas Negeri Medan \\ North Sumatra, Indonesia
}

\begin{abstract}
This study aims to reveal the application of communication, resources, and implementation of the bureaucracy in the PPDB zoning area system policy. In SMA 1 Sunggal, Deli Serdang Regency. The data was obtained by using a tiered interview technique, namely the North Sumatra Province Education Office, School Principals, Teachers, Parents, and Students. Researchers used interview guidelines. Furthermore, it is processed and discussed with narrative techniques. The data obtained, the policy about the zoning system has been communicated to the organizers and the public, but there are people who are still not aware that this policy will even level the quality of education and eliminate the label of superior schools, vaforit schools, but there are people who are not fully aware of it so there is falsifying SKTM; The available resources are already trained and understand what is being done with supporting facilities, but are constrained by electricity and the internet network as well as the hassle of bursting with registrants. Disposition related to the characteristics of an honest and procommunity organizer, the funds needed from BOS. Regarding bureaucracy, there is support from the center to the regions, but there is still interpretation in the regions in the application of zoning.
\end{abstract}

\section{Keywords- policy; implementation;zone;system}

\section{INTRODUCTION}

Acceptance of New Students, hereinafter abbreviated to PPDB is the acceptance of new students in kindergartens and schools as mandated in the Regulation of the Minister of Education and Culture of the Republic of Indonesia Article 1 paragraph 7, Number 51 of 2018. Reception of new students is an activity of an educational institution namely schools, where do new student admissions in order to filter out potential participants who register themselves at the destination school. New students who pass must meet the criteria determined by the school through the stages: registration, test selection, and announcement of acceptance of new students [1].

Management of education by leaders is directed towards achieving the quality of education, this management is one of the provisions contained in eight national national education standards in accordance with PP. RI No. 19 of 2005 concerning National Education Standards in article 2 paragraph 1 (1) content standards, (2) process standards, (3) graduation competency standards, (4) education personnel education standards, (5) standards facilities and facilities, (6) management standards, (7) financing standards, and (8) education assessment standards). In line with that Minister of Education and Culture Muhazir Effendi stressed that the PPDB zoning system is implemented which is an effort of the government in terms of equalizing the quality of education in various parts of Indonesia, in addition prospective students who have above average abilities in academic matters will spread and not gather in some schools that are often referred to by the community as superior schools in the area, "all schools must be favorite schools. Hopefully there will be no more low quality schools".

Facts on the field can be stated that the rules are clear, socialization has also been carried out, but the fact is that some have surfaced, namely: education practitioner Andi Arif "The main problem in the implementation of the PPDB zoning system is not the distance between residences and schools but more on equalizing the quality of education".

This shows that the government has not been able to fulfill the mandate of Law Number 20 Year 2003 concerning the National Education System Article 11 paragraph (1) which guarantees equal rights for every citizen to get quality education. Based on this description, this paper would like to analyze government policy regarding the implementation of the PPDB 2018/2019 zoning system with the jury: Analysis of the Implementation of the 2018/2019 Ppdb Zoning System In SMA Negeri 1 Sunggal, Deli Serdang Regency.

\section{LITERATUR REVIEW}

\section{A. Public Policy Implementation}

Implementation of policies in principle is a way for a policy to achieve its objectives. Policies are derived in the form of programs which are then reduced to projects, and ultimately manifest in activities, whether carried out by the government, the community or government cooperation with the community.

Van Meter and Van Horn in [2] defines the implementation of public policy as actions in previous decisions. Implementation is understanding what actually happens after a program is declared effective or formulated is the focus of attention to the implementation of the policy ie the events and activities that arise after the enactment of State 
policy guidelines that cover both efforts to administer them and to cause consequences / impacts real to the community or events quoted in the book of [3].

From the above explanations it can be concluded that policy implementation will not begin before the goals and objectives are set or identified by policy decisions. There are several theories from experts regarding the implementation of policies, namely:

\section{1) Theory of George C. Edward}

Edward III [4] holds that policy implementation is influenced by four variables, namely: (a) Communication, (b) Resources, (c) Disposition, and (d) Bureaucratic Structure. Stadar Operational Procedure (SOP) or work procedures, basic measures develop as an internal response to the limited time and resources of the implementers as well as the desire for uniformity in the workings of complex and widespread organizations. Whereas fragmentation comes from pressures outside bureaucratic units, such as legislative committees, interest groups of executive officials, state constitutions and the nature of policies that influence government bureaucratic organizations.

\section{2) Merilee S. Grindle's Theory}

The success of implementation according to Merilee S. Grindle in [4] is influenced by two large variables, namely the content of policy and the context of implementation, while Wibawa in [5] suggests that the Grindle model is determined by the contents of the policy and the context of its implementation. The basic idea is that after the policy is transformed, then the implementation of the policy is carried out.The success is determined by the degree of implementability of the policy. a) The type of benefits to be generated, (b) The degree of change desired, (c) The position of the policy maker, (d) Who, program implementers, and (e) Resources produced.

While those related to the context of implementation are: (a) The power, interests and strategies of the actors involved, (b) Characteristics of institutions and authorities, and (c) Compliance and responsiveness.

The uniqueness of the Grindle model lies in its comprehensive understanding of the policy context, particularly with regard to the implementor, the recipient of the implementation, and the arena of conflict that may occur between the implementing actors, as well as the conditions of implementation resources needed.

3) Theory of Donald S. Van Meter and Carl E. Van Horn

According to Meter and Horn in [4] there are five variables that affect implementation performance, namely policy standards and targets, resources, communication between organizations and strengthening activities, characteristics of implementing agencies and social, economic and political conditions.

According to Edward III's view [6] the policy communication process is influenced by three important things, namely: (1) transmission, (2) consistency, and (3) research.

\section{B. Functions of Management, Education and Student Management}

Management functions consist of planning (planning), Organizing / organizing functions, leadership / directing leading functions, controlling / contorlling functions. This control function, is the activity of assessing or comparing performance based on standards that have been set and then made improvements. "Educational management is a field of study and practice concerned with the operation of educational organizations" [7]. Educational management is a field of study and practice related to the implementation of educational organizations.

Student management; Students as students are one of the inputs that determine the success of the education process. Management includes the admission of new students, guidance and counseling services, management of students in the classroom, management of intraschool student organizations and management of data about students. The aim of student management is to regulate student activities so that these activities support the learning process in educational institutions (schools); so that the learning process can run smoothly, orderly and regularly so that it can contribute to the achievement of school goals and overall educational goals. The general objective of learner management is to organize student activities so that these activities support the teaching and learning process in schools.

Stages of acceptance of new students, including 1) the formation of the committee, 2) determination of the requirements and time of registration, 3) determination of registration administration needs, 4) announcement of registration, 5) implementation of the selection, 6) determination of candidates received, 7) announcement of the results of the selection, and 8) re-registration.

Schools must prepare appropriate strategies in implementing them, so that they can attract qualified students as better school inputs so that the learning process can be maximized and the quality of the school increases.

\section{METHODOLOGY}

This type of research conducted in this study uses quantitative research. "Quantitative research is a research that is concerned with data depth. The research technique used in this study uses descriptive research techniques.Time and Place of Researchthis study was carried out in the span of 15 February to 24 May 2019 in SMA Negeri 1 Sunggal Deli Serdang. Research Subjectsare presented in the following table:

\begin{tabular}{|c|l|c|}
\hline No & Research Subjects & Total \\
\hline 1 & $\begin{array}{l}\text { Head of ProvsuaPercut } \\
\text { Pending Service Branch }\end{array}$ & 1 person \\
\hline 2 & Headmaster & 1 person \\
\hline 3 & Teacher & 1 person \\
\hline 4 & Students & 1 person \\
\hline 5 & Parents & 1 person \\
\hline Total & 5 Person \\
\hline
\end{tabular}

This type of research data is primary through Interview and secondary data is Document available, which is also 
related to respondents. The data sources are Kels X semester 2 high school students, Teachers, Operators, Principal of 1 Sunggal Deli Serdang High School, and Serdang Deli Percut Department.The authors obtained and collected this research data using Interviewing techniques and tools. Use a hero-guide tool in accordance with ritual techniques.

\section{RESULTS AND DISCUSSION}

\section{A. Research Results}

As stated in the research methodology that the respondents consisted of five people, namely one student parent, one student, one operator receiving new students, one teacher who also doubles the headmaster of student affairs, one Principal, and one Head of the Percut Education Office in the Deli Tengah Regency of North Sumatra Province.

Interview results for these four subjects are described in narrative form, presented in the form of questions and answers adopted from Gorge C Edward's theory as follows:

1) What is the clarity, consistency, goals, and policy objectives of the PPDB Zoning Zone System?

This zoning system is a policy of the central government in this case the Minister of Education and the Republic of Indonesia, which has a vision that at one time there were no favorite schools, superior schools, or other similar names where one school was considered good and another was considered not good, or quality and not qualified. So this is clearly done by the school in accepting students. With regard to consistency in its implementation, it remains consistent in accordance with SOPs and applies to all schools managed by the government or public schools. Have a clear purpose. The target of this policy is students as new students.

The special thing found in the field is that parents are surprised that their children can be accepted in the schools around their places of residence, whereas previously the school only accepted smart children, passed strict selection, and came from established families economically, socially and the like. Thus students are surprised and feel unreasonable to be accepted in a school that was known to be of good quality, a favorite while his brother who applied two years ago was not accepted before this policy was applied. But not a few also do not register because they have not heard the information and ways that apply in the zoning system.

2) How is the hierarchical cohesiveness of the School, Department of Education Provision of the Ministry of Education and Culture of the PPDB Zoning Area System?

Integration of the hierarchical administration, there is integration because this is central policy, so all implementers at various levels perform roles according to level, namely the central level makes policy, the Provincial Education Office makes Pergub, the Education Office Branch carries out socialization, and schools carry out in accordance with SOP and results socialization.

3) What are the implementing regulations of the Ministry of Education and Culture on the PPDB Zoning Zone System?
Related to the zoning system, it has been stipulated in Permendikbud No. 14 of 2018 that all schools organized by the Regional Government are obliged to accept students from school zoning, except due to Geographical factors of the 3T regions (outermost, isolated, poorest). The obligation referred to is $90 \%$ of the zoning area, $5 \%$ due to achievement, and $5 \%$ due to other factors such as natural disasters and relocation of parents' duties.

4) What is openness to the community about PPDB Zoning Area System?

Openness of information to the public is clear and cannot be covered up because everything is online, everyone can see on the internet, print media and even manually published on Mading (wall magazine) schools [8]. However, it is undeniable that there are still parents who have not been literate in technology (information technology-IT), more than that there are still parents who think that their children cannot be accepted in schools that were considered favorite, because there are schools around the house used to be a well-known school, [7] though some regretted it after being "information overdog" and had registered their child in a private school, because they considered their child to have the ability and achievements of a previous level of school.

5) How do the implementers consistently provide clear/unchanging instructions about the PPDB Zoning Zone System?

The implementers, Principals, Teachers, and Operators remain consistent in the implementation of activities, because everything has been set up in manual and online technical guidelines.

6) Have the trainers been given training so that they are competent in implementing the PPDB Zoning Zone System?

Implementers, Principals, Teachers have been given and received socialization, operators have also been given training to use computer applications related to zoning based PPDB on-line. So technically there are no obstacles.

7) What is the support of the central and regional leaders, including the DPRD regarding the PPDB Zoning Zone System?

Central pipeline support, clearly with the issuance of Permen-Dikbud No. 14 of 2018, the support of regional leaders with the issuance of Governor Regulation No. 22 of 2018 supported by Forkopinda (Regional Leaders Communication Forum) consisting of the Governor of North Sumatra, the Chair of the North Sumatra High Court, the Head of the North Sumatra High Prosecutor's Office, Pangdam IBB, and North Sumatra Police Chief.

8) What is the commitment of the Organization (leadership and all staff) regarding the PPDB Zoning Zone System?

The commitment of the school organization (leaders and all school staff) all provides positive support, however as a national policy, is still supported as optimally as possible. Because there are technical guidelines, so that each school personnel take responsibility according to their respective duties and functions. 
9) Where are the sources of funds used in the PPDB Zoning Area System activities?

The source of funds used in the PPDB zoning area activities is BOS (School Operational Assistance) funds, which have been budgeted by each school in accordance with BOS operational guidelines.

10) What is the balance betweenbudget and activities, PPDB Zoning Area System?

There is no problem with the budget balance between available funds and activities, because previously it has been budgeted in the submission of BOS funds, especially those intended for PPDB activities.

11) What is the availability of supporting facilities (buildings, facilities, materials, offices, suppliers) in the PPDB Zoning Zone System?

Availability of supporting facilities such as work space, electric lighting, air conditioning, Wi-fi networks, and in ready to use conditions.

12) What is the implementation of the Audit in PPDB Zoning Area System activities?

In this activity there is no audit, there is an evaluation of the activity, because the PPDB zoning system is an inseparable part of school activities, the North Sumatra Provincial Education Office Branch and the North Sumatra Provincial Education Office. So the Audit took place in the activities of the North Sumatra Provincial Education Office not in the school PPDB zoning system.

TABLE 2. RESULT OF INTERVIEWS RESEARCH

\begin{tabular}{|c|c|c|c|c|c|}
\hline \multirow[b]{2}{*}{ Policy Point } & \multicolumn{5}{|c|}{ INFORMAN } \\
\hline & $\begin{array}{c}\text { Head of } \\
\text { Departme } \\
n t\end{array}$ & $\begin{array}{c}\text { Headmast } \\
\text { er }\end{array}$ & Teacher & Students & Parents \\
\hline $\begin{array}{l}\text { Communica } \\
\text { tion }\end{array}$ & Done & Done & Done & Undone & $\begin{array}{l}\text { Undon } \\
\text { e }\end{array}$ \\
\hline Resource & Good & Good & Good & Good & Good \\
\hline Disposition & Well & Well & Well & - & - \\
\hline $\begin{array}{l}\text { Bureaucrac } \\
\text { ySupport }\end{array}$ & Well & Well & Well & - & - \\
\hline
\end{tabular}

\section{B. Discussion}

Based on the research data that has been revealed both in the analysis, the following discussion is based on the primary data that has been collected from respondents, divided into four parts: communication groups, resources, dispositions, and bureaucracy, as follows:

Communication is an important part of the Zoning-based PPDB policy, Professor of the Indonesian Education University (UPI) Cecep Darmawan assesses the Acceptance of New Students (PPDB) with the zoning system is not ideal or not suitable to be applied. Because, not all regions have schools with the same standards. He emphasized that whatever PPDB system is implemented, it must be a measure of the quality of education. Moreover, the government has set eight education standards. "The purpose of PPDB through zoning is to equalize education so that the quality of schools is evenly distributed. But unfortunately, zonation based on this region does not see several aspects, for example regional diversity, then regions also have aspirations that should be accommodated by the center," (On Air at PRFM, Saturday 18 May 2019).

Education observer Doni Koesoema considers irregularities to be an impact of Minister of Education and Culture Regulation (Permendikbud) No. 17 of 2017 on PPDB. "This must be an error in understanding the Minister of Education and Culture regarding zoning. Some regions misinterpret this rule by scoring so that the distance criteria only "One of the measurements," said Doni when contacted by Okezone, July 12, 2017. The Ministry of Education and Culture must communicate with the local government to ensure that the zoning system runs well according to regulations, "he said.

Competent human resources in implementing zoning policies are available with training before the implementation of activities, they are only constrained by the increasing number of participants who register as the writer [2] said. Likewise political support, it cannot be denied that the interests of local parties still occur, but do not affect the whole. Organizational commitment from the center to the regions up to the level of implementation is going well. Efforts to evaluate the zoning system policy implementation process can be done through the concept of effectiveness. This concept is one of the factors to determine whether significant changes need to be made to the form and management of student acceptance of a new zoning system or not. So there is no specific audit at the organizer level because the funds used are BOS refere to the [4] statement. Available facilities such as workspace, internet and electricity facilities. This internet facility is disrupted due to network load or load due to the large number of uses.

Disposition, the characteristics of field implementers such as commitment, honesty, and democratic nature have been shown by the field implementers, because of their understanding of the task [7]. The organizer's commitment is that they prioritize the interests of the community, but now the community has a commitment that needs to be questioned when one of the zonasil conditions is SKTM (certificate of being unable), there are only parents who are in fact economically capable, but offer SKTM so that their children are accepted, also occurs in the proximity of a place of residence, there are just parents who are reckless, telling their children to stay the last six months in a neighbor's / family's house so that their child can be accepted at the desired school.

Bureaucracy, the support of implementing agencies, this has become the nature of bureaucrats to obey and obey the leadership. Therefore even though the conscience of the implementers (PPDB committee) expressed rejection, in its implementation the PPDB committee still carried out what was the decision of the Office of Education as its parent organization [7], whatever was thought by the implementing personnel, but when we think positively on what they do and the final results of the work, should be appreciated for the advancement of education in Indonesia. This policy seems simple and on the ground there are pros and cons, but the ultimate goal is to eliminate the equal distribution of education quality, and eliminate the impression of vaforit and non- 
vaforite schools. Uniformity of motion is needed in each region supported by research data. So that in turn all of Indonesia works the same way.

\section{A. Conclusions}

\section{CONCLUSION AND SUGGESTION}

Based on the analysis and discussion of the data in this survey, the following conclusions are made:

1) Policy communication to the organizers and especially the community is needed to achieve the objectives of the zoning system policy.

2) The available resources in the form of human, infrastructure are very necessary for the passage of a policy.

3) Disposition, in terms of the characteristics of the organizers at the field level, financial support, public awareness is needed to be in line with the policies implemented in the zoning system, so there is harmony between the organizers and service recipients (parents and prospective students)

4) A simple bureaucracy supports the smoothness of zoning system policies in schools.

\section{B. Suggestions}

Socialization is needed to the public about the zoning system in depth with clear techniques, and clear sanctions for violators, SOPs need to be revised so that uniform implementation in the field.

\section{ACKNOWLEDGMENT}

This paper and the research behind it would not have been possible without the exceptional support of my lecturer, Eka Daryanto. For this chance I also would like to say may thanksful to Mr. Basir Hasibuan as the head of Sunggal Deli Serdang branch Office in support this study. And thanks to AISTEEL reviewers in correcting this paper to be better and best.

\section{REFERENCES}

[1] M. Imam Ardi dkk. Evaluasi Manajemen Penerimaan Peserta didik Baru Sistem Real Time OnLine Dinas Pendidikan Kota Yogyakarta, Yogyakarta, Jurnal Penelitian Ilmu Pendidikan, Vol. 8, Nomor 1, Maret 2015

[2] M. Jainal Abidin dan Asrori, Peranan Sekolah Berbasis Kawasan Zonasi dalam Pembentukan Karakter di SMP Negeri 15 Kedung Cowek Surabaya, Surabaya, Jurnal Pendidikan Islam, Vol.7, No.1, 2018 hal, 120

[3] Media Komunikasi dan Inspirasi, JENDELA, Pendidikan dan Kebudayaan, Jakarta, Jurnal Kemendikbud, ISSN: 2502-7867, XII/Juli, 2017, hal. 1-36

[4] Purwanti, Dian. 2018, Efektivitas Kebijakan Penerimaan Peserta Didik Baru Sistem Zonasi Bagi Siswa Rawan Melanjutkan Pendidikan, Jurnal, Sukabumi, Univ Muh. Sukabumi.

[5] Siska Permata Sari, Jurnalis ·Rabu 12 Juli 2017 14:22 WIB OKE News Sistem Zonasi Bermasalah,

[6] Kemdikbud Harus Komunikasi dengan PemdaTim Pikiran Rakyat Sabtu, 18 Mei 2019, 14:02

[7] Ulfah, asri. Dkk. 2016. " Efektivitas Penerimaan Peserta Didik Baru (PPDB) Melalui Sistem Penerimaan Peserta Didik Online”. Diakses pada

[8] Yustin, Fartina dkk. Kajian Kepuasan Pengguna Informasi Penerimaan Peserta Didik Baru (PPDB) Online, Sukabumi, JurnaL IJCIT (Indonesia Journal on Computer and Information Technology, Vol.2, No.2, Nopember 2017 hal 48-54 